\title{
APLIKASI PEMBERIAN RANSUM FERMENTASI BERBASIS BAHAN PAKAN LOKAL BAGI PETERNAK ITIK DI KECAMATAN LIANG ANGGANG KOTA BANJARBARU
}

\author{
Siti Dharmawati dan Nordiansyah Firahmi \\ Fakultas Pertanian, Jurusan Peternakan, Universitas Islam Kalimantan MAB \\ Email : dharmauniska@gmail.com
}

\begin{abstract}
ABSTRAK
Pengabdian pada masyarakat ini bertujuan untuk menambah wawasan peternak mitra untuk memanfaatkan bahan - bahan pakan yang megandung serat kasar dengan cara fermentasi sehingga lebih mudah dicerna unggas.

Mitra yang dilibatkan dalam kegiatan Ipteks Bagi Masyaraka (IbM) ini adalah sebanyak 2 (dua) orang mitra peternak unggas dengan spesialisasi pemeliharaan itik petelur yang tinggal di lingkungan Kecamatan Banjarbaru Utara dan Kecamatan Liang Anggang dan berkomitmen kuat untuk mengembangkan usaha peternakannya dalam mendukung peternakan itik di Kota Banjarbaru, dengan jumlah itik yang dipelihara sebanyak 500 sampai dengan 800 ekor.

Metode yang dilaksanakan dalam kegiatan ini berupa penyuluhan, bimbingan teknis pengolahan pakan fermentasi dan pemberian pakan tersebut pada itik fase petelur. Hasil kegiatan menunjukkan bahwa peternak mitra sudah memahami dan mampu menerapkan teknologi yang diberikan dan sudah diterapkan pada ternaknya.
\end{abstract}

Kata Kunci: Ransum fermentasi, bahan pakan local, peternak itik, Kecamatan Liang Anggang, Kota Banjarbaru

\section{PENDAHULUAN}

Kota Banjarbaru merupakan salah

Kabupaten Kota yang cukup potensial untuk pengembangan peternakan salah satunya adalah peternakan itik. Beberapa keunggulan yang dimiliki Kota Banjarbaru antara lain adalah (a) sumber daya lahan yang cukup subur untuk pengembangan bahan pakan makanan ternak (b) potensi SDM peternak yang cukup banyak (c) Respon peternak itik yang cukup baik terhadap inovasi teknologi baru (d) Lokasi wilayah yang cukup strategis sehingga memiliki prospek pasar yang baik bagi Kalimantan Selatan bahkan Kalimantan Timur dan Tengah.

Mitra yang dilibatkan dalam kegiatan Ipteks Bagi Masyaraka (IbM) ini adalah sebanyak 2 (dua) orang mitra peternak unggas dengan spesialisasi pemeliharaan itik petelur yang tinggal di lingkungan Kecamatan Banjarbaru Utara dan Kecamatan Liang Anggang. Mitra pertama yang dilibatkan adalah peternakan itik " Budi" yang tinggal di Kecamatan Banjarbaru Utara dengan profil dari mitra ini adalah : (1) 
Peternakan itik Budi mulai terbentuk pada tahun 2014, dengan jumlah ternak yang dipelihara sebanyak 600 ekor itik petelur spesialisasinya itik Alabio dan 300 ekor ayam petelur. (2) Luas areal peternakan itik yang dikembangkan $4000 \mathrm{~m}^{2}$. Itik yang yang dipelihara sebagian besar adalah itik petelur jenis itik Alabio yang dipelihara secara intensif dengan menggunakan kandang panggung sistem koloni. (3) Rata-rata produksi telur yang dihasilkan mitra adalah $95 \%$ dari jumlah ternak dengan harga penjualan telur berkisar antara Rp. 2000 s.d. Rp 2500 per butir telur. Rata-rata berat telur yang dihasilkan 60 gram/butir sampai 75 gram/butir.

Mitra kedua yang dilibatkan dalam kegiatan IbM ini adalah peternakan itik Sri Sugiarto. Dipilihnya mitra ini dengan alasan (1) Spesialisasi utama peternakan itik yang dipelihara adalah itik petelur dengan skala usaha 500 sampai 800 ekor itik, dengan jenis itik yang dipelihara adalah itik Mojosari, Itik Bali serta itik persilangan itik Mojosari dengan itik Alabio (2) Mitra ini suka ber eksperimen mulai dalam hal penggunaan pakan. (3) Luas areal peternakan $2000 \mathrm{~m}^{2}$ dengan kandang panggung sistem koloni (4) Rata-rata produksi telur yang dihasilkan $60-75 \%$ dengan berat telur berkisar antara 50 sampai dengan 70 gram/butir.

Permasalahan utama yang dihadapi oleh kedua mitra tersebut adalah (1) Harga pakan yang tidak stabil (2) Kurangnya minat peternak dalam membuat formulasi pakan sendiri karena ada anggapan bahwa formulasi pakan yang dibuat kualitasnya lebih rendah dibandingkan pakan pabrik (3) Ketersediaan bibit unggul yang tidak kontinyu (4) Kurangnya pemahamanan terhadap penanganan penyakit dan pencegahan penyakit. Permasalahanpermasalahan tersebut di atas terjadi disebabkan oleh : (1) Kurangnya informasi tentang hasil-hasil penelitian yang langsung menyentuh ke peternak terutama dalam hal pengolahan pakan dan teknologinya (2) Rendahnya kemampuan dan keterampilan peternak dalam mengolah bahan-bahan pakan potensial yang mengandung anti nutrisi menjadi bahan pakan yang bernutrient tinggi (3) Kurangnya kesempatan bagi peternak untuk ikut pelatihan dan magang di perusahaan-perusahaan besar dan komersil di luar daerah.

\section{METODE PELAKSANAAN}




\begin{abstract}
Metode pendekatan yang dilaksanakan untuk mendukung realisasi program IbM bagi peternak mitra adalah sebagai berikut :

1. Wawancara langsung kepada para peternak
\end{abstract}

2. Pelatihan teoritis dengan teknik pemeliharaan itik alabio secara umum (pengenalan bibit, sistem perkandangan, metode pemberian ransum dan penanganan penyakit), teknik pengolahan dan pengawetan pakan khususnya pengolahan dan pengawetan pakan.

3. Pelatihan dalam hal manajemen usaha peternakan itik secara profesional

4. Praktek langsung yang dilaksakanakan oleh mitra dengan bimbingan tim pengusul $\mathrm{IbM}$ meliputi kegiatan penyiapan bibit itik (DOD), cara memilih dan mengenali bahan-bahan pakan yang berkualitas, perhitungan nilai gizi ransum, menyusun dan membuat formulasi ransum, pencampuran ransum, pembibitan itik, penangananm penyakit dan biosekuriti, pemilihan telur tetas dan cara penetasan agar berhasil.
5. Pengadaan alat berupa mesin tetas sederhana, oven pengering dan pencacah pakan.

6. Pengamatan terhadap tingkat kesukaan itik terhadap bahan pakan yang diolah, produksi telur, dan daya tetas telur setelah dilakukan pengujian dengan menggunakan mesin tetas yang digunakan.

7. Bersama dengan mitra melakukan pencatatan terhadap produktivitas itik meliputi produksi telur, berat telur, respon itik terhadap pakan, daya tetas telur dan kondisi kandang.

\section{Solusi}

Solusi yang diperlukan oleh mitra pada saat ini adalah

1) pengetahuan dan keterampilan serta penguasaan metode/teknik pengolahan bahan pakan lokal bagi ternak itiknya yaitu berupa bahan -bahan pakan lokal

2) Pelatihan teoritis (metode kelas) teknik pemeliharaan itik alabio secara umum (pengenalan bibit, sistem perkandangan, metode pemberian ransum dan penanganan penyakit), teknik pengolahan dan pengawetan pakan khususnya pengolahan dan pengawetan pakan sumber 
protein keong rawa "kalambuai" dan kepala udang dengan menggunakan metode silase, cara pencampuran bahan, pemilihan bahan, cara penyimpanan bahan sampai terbentuknya bahan pakan. Selain itu diajarkan juga pada para anggota mitra beberapa metode pencampuran ransum yang tepat dengan memanfaatkan bahan-bahan pakan lokal yang murah, mudah diperoleh, tidak mengandung anti nutrisi, bernilai gizi tinggi sehingga dihasilkan ransum itik yang berkualitas dan mampu meningkatkan produksi ternak itik.

3) Pelatihan pemilihan bibit unggul untuk dibibitkan sehingga menghasilkan telur tetas yang baik dan cara memilih telur tas yang baik.

4) Pengadaan alat berupa mesin tetas sederhana, oven pengering dan pencacah pakan..

5) Praktek langsung yang dilaksakanakan oleh mitra dengan bimbingan tim pengusul $\underline{\text { IbM meliputi kegiatan }}$ penyiapan bibit itik (DOD), cara memilih dan mengenali bahan-bahan pakan yang berkualitas, perhitungan nilai gizi ransum, menyusun dan membuat formulasi ransum, pencampuran ransum, pembibitan itik, penangananm penyakit dan biosekuriti, pemilihan telur tetas dan cara penetasan agar berhasil. Bimbingan ini dilakukan sampai mitra dianggap cukup terampil dan menguasai materi.

\section{HASIL DAN PEMBAHASAN}

Kegiatan pengabdian yang telah dilakukan berupa diskusi untuk kesepakatan kegiatan yang akan dilakukan baik berupa jadwal kegiatan, penyuluhan, praktek pembuatan pakan dan pemberian kepada ternak (Gambar 1 dan 2)
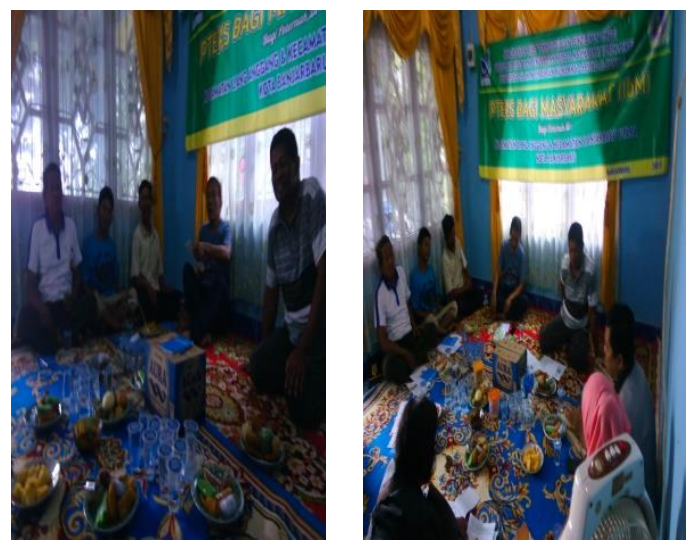

Gambar 1 dan 2. Kegiatan Penyuluhan dengan mitra. 
Setelah dilakukan penyuluhan untuk petani ternak, maka dilakukan praktek pembuatan pakan fermentas dengan terlebih dahulu mendatangkan bahan-bahan (Gambar 3) dan bersama-sama dengan peternak melakukan praktek membuat pakan fermentasi (Gambar 4)
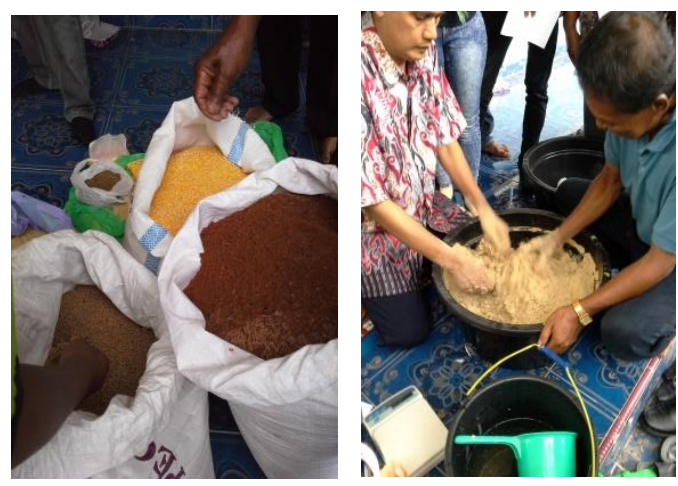

Gambar 3 dan 4. Bahan-bahan pakan yang digunakan (kiri) dan Praktek pembuatan pakan fermentasi (Dedak dan Ampas Sagu) (kanan)

Bahan campuran dalam
pembuatan pakan fermentasi adalah dedak padi atau ampas sagu sebanyak $50 \mathrm{~kg}$ dicampur dengan ragi tape sebanyak $2 \%$ dari berat bahan yang digunakan, mineral B12 sebanyak 15 gram. Bahan-bahan tersebut diaduk sampai homogen mulai dari bahan yang jumlahnya paling sedikit kejumlah bahan yang paling banyak. Kemudian campuran yang sudah homogen dimasukkan ke dalam drum plastic atau bak plastik dengan cara dipadatkan dan pada permukaannya ditutup dengan daun pisang (Gambar 5). Selanjutnya bahan- bahan pakan lokal yang sudah difermentasi tadi disimpan selama 3-5 hari secara an aerob. Setelah bahan pakan dapat digunakan dengan cara dicampur dengan bahan bahan pakan lain. Biasanya bahan pakan hasil fermentasi dapat digunakan antara 30$40 \%$ dalam ransum.

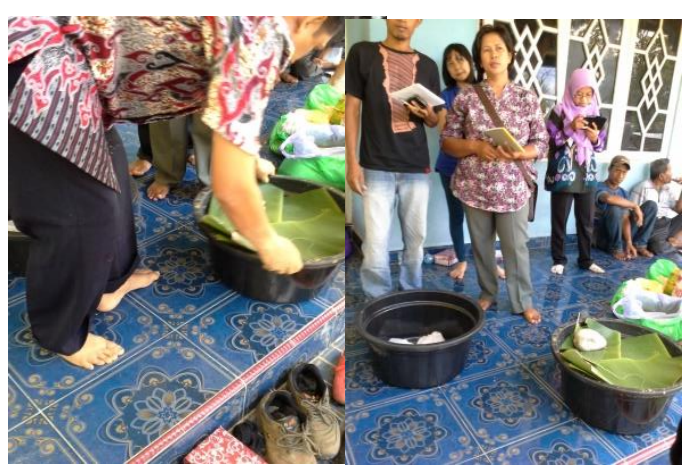

Gambar 5 dan 6. Proses Penutupan bahan pakan fermentasi

Dari hasil kegiatan pengabdian ini secara umum petenak sudah memahami cara pembuatan pakan fermentasi dengan berbagai bahan pakan lokal, dan sebagaian sudah menerapkannya sebagai bahan campuran ransum itik fase petelur yang dipelihara secara intensif.

Penggunaan pakan fermentasi dalam ransum ini merupakan salah satu alternative yang dapat digunakan untuk mengurangi biaya ransum yang 
cukup tinggi dengan harga pakan komersial yang terus meningkat

Hasil pengamatan dan observasi menunjukkan bahwa ternak itik yang diberi ransum fermentasi ransum menunjukkan performans yang baik. Selain itu lingkungan kandang tidak berbau, konsumsi ransum itik meningkat dan daya tahan tubuh ternak baik.
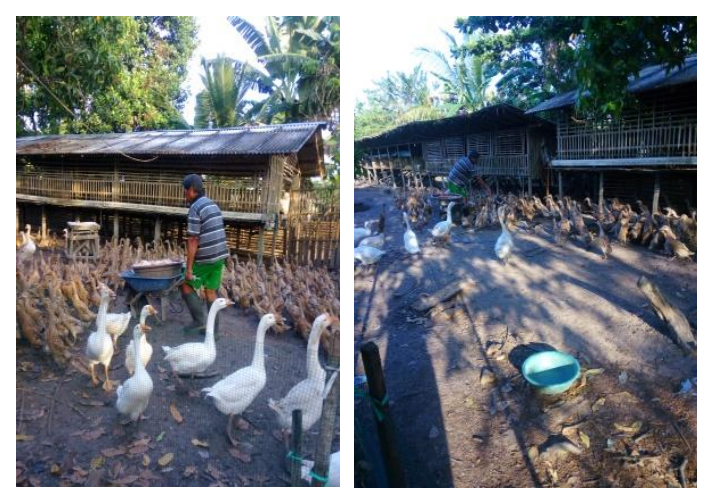

Gambar 7 dan 8. Peternak mitra memberi pakan pada itik
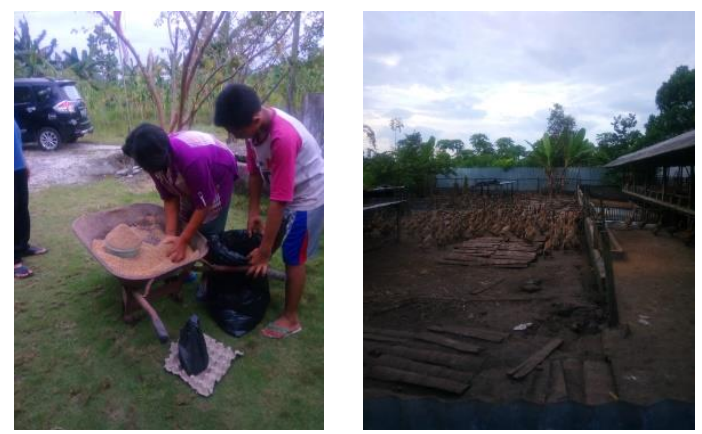

Gambar 9 dan 10. Mitra sedang memfermentasi pakan (kiri) dan Itik yang diberi ransum fermentasi (gambar kanan)

\section{KESIMPULAN}

Kesimpulan dari kegiatan pengabdian ini adalah peternak sudah memahami dan menerapkan pembuatan pakan fermentasi untuk kebutuhan ternak itik yang dipeliharanya terutama itik yang dipelihara secara intensif.

\section{DAFTAR PUSTAKA}

Anonim, 2014. Kecamatan Banjarbaru Utara dalam Angka. Badan Pusat Statistik Pemerintah Kota Banjarbaru, hal : 36

Anonim, 2014. Kecamatan Liang Anggang dalam Angka. Badan Pusat Statistik Pemerintah Kota Banjarbaru, hal : 45

Dharmawati, 2008-2009. Kajian Nutrien Keong Rawa "Kalambuai" di Rawa Kalimantan Selatan dengan Menggunakan Metode Pengolahan Berbeda dan Penggunaannya pada Itik Alabio

Dharmawati, Firahmi, 2015. Penerapan Teknologi Pengolahan Pakan Fermentasi Bagi Kelompok Ternak Itik di Kelurahan Landasan Ulin Barat Kecamatan Liang Anggang Banjarbaru. Al Ikhlas Jurnal Pengabdian. Volume 1 No. 1 (2015) ojs..uniskabjm.ac.id. 